\title{
PRESENTING THE OTTOMAN HERITAGE: AN EXHIBITION OF ISLAMIC MANUSCRIPTS IN ZAGREB
}

\section{Tatjana Paić-Vukić}

The Croatian Academy of Sciences and Arts

ABSTRACT

\begin{abstract}
The paper proposes specific considerations in the presentation of the Ottoman heritage, using the example of an exhibition of Islamic manuscripts held in Zagreb, Croatia, in 2014, including the representativeness of certain exhibits, the importance of taking the vague notions of Ottoman history and culture among the wider public in Croatia into account, and the cultural-educational functions of such an event. In addressing these issues, I draw upon my experience as the author of the aforementioned exhibition and accompanying catalog. ${ }^{1}$
\end{abstract}

\section{INTRODUCTION}

In May 2014, an exhibition of Islamic manuscripts from the holdings of the Oriental Collection of the Archives of the Croatian Academy of Sciences and Arts, jointly organized by the Academy and the Yunus Emre Institute from the Republic of Turkey, was held in Zagreb. ${ }^{2}$ While devising the conceptual framework, selecting the exhibits and writing the catalog, I considered various approaches to the presentation of the Ottoman cultural heritage, frequently reconsidering my choices and decisions. This paper summarizes my experience and addresses a set of questions that arose.

The Oriental Collection of the Archives of the Croatian Academy of Sciences and Arts was founded in Zagreb in 1927, following years of efforts by Croatian academicians to initiate the collecting of Ottoman sources for the history of Southeast Europe. The materials were mostly gathered in Bosnia and Herzegovina, and to a lesser extent in Kosovo, Sandžak and Macedonia. Today, with 2,109 codices comprising around 3,300 complete works and fragments in Arabic, Turkish and

1 Although the topic of this paper does not fall within the scope of the main scholarly interests of Prof. Nenad Moačanin, I gladly submit it as a contribution to the volume to be published in his honor, knowing his curiosity about all fields of Oriental studies, be it economic history, demography, Persian poetry or visual arts.

2 "Riječ, pismo, slika. Iz riznice Orijentalne zbirke Arhiva Hrvatske akademije znanosti i umjetnosti” [Text, Calligraphy and Painting. Treasures of the Oriental Collection of the Archives of the Croatian Academy of Sciences and Arts], $12^{\text {th }}-31^{\text {st }}$ May 2014. The Strossmayer Gallery of Old Masters, Croatian Academy of Sciences and Arts, Zagreb. 
Persian, it is the largest collection of Arabic-script manuscripts in Croatia, and one of the largest collections of its kind in Southeast Europe. In addition to the manuscript books, mainly originating from the Ottoman Empire, it has 760 Ottoman documents dating from the sixteenth to the twentieth centuries.

Since the founding of the Collection, the manuscripts could only be viewed by researchers in the reading room of the Academy's Archives. Individual manuscripts and documents have occasionally been displayed at various thematic exhibitions in Croatian museums and galleries. In 1986, Muhamed Ždralović, then the curator of the Collection, prepared an exhibition of 36 manuscripts from its holdings in the Atrium of the Palace of the Croatian Academy of Sciences and Arts and wrote a catalog. ${ }^{3}$ Almost three decades later, I decided to organize a new exhibition.

\section{ASSESSING THE PRIOR KNOWLEDGE OF THE VISITORS}

While preparing the exhibition I was in contact with several Turkish colleagues from the Yunus Emre Institute, informing them of my manuscript selections and the progress of my work. In our collaboration, we occasionally disagreed on certain points and discussed some parts of my introductory text in the catalog, which they found superfluous, while I considered them necessary. These disagreements probably resulted from our living in different cultural environments, the one where local visitors to such exhibitions are familiar with Islamic culture and Ottoman history, and the other where the Islamic heritage is only vaguely familiar and mostly perceived as cultural otherness. In my view, exhibiting Islamic manuscripts in Croatia requires insight into the prevailing perceptions of Islamic culture among the wider public and a thoughtful approach to the informative, didactic and educational aspects. As Kratz puts it, "exhibition experience is inherently double-sided, based on the mediating role of exhibitions: it relies both on what visitors bring to exhibitions as well as what exhibitions bring to visitors, which is already the outcome of complex processes and decisions that shaped the exhibition." ${ }^{\prime 4}$

I started from the assumption that the general public in Croatia knows very little about Islamic civilization, and even less about the Islamic book culture. What schoolbooks taught us and still teach our children is mostly limited to some basic facts about the religion, Muhammad as a prophet and statesman, the expansion of the Islamic state and the Crusades, ${ }^{5}$ with almost no mention of great scientific and

$3 \quad$ Muhamed Ždralović, Arabički rukopisi Orijentalne zbirke Arhiva Jugoslavenske akademije znanosti i umjetnosti. Katalog izložbe povodom 120. obljetnice osnutka Jugoslavenske akademije znanosti $i$ umjetnosti (Zagreb: JAZU, 1986).

4 Corinne A. Kratz, "Rhetorics of Value: Constituting Worth and Meaning through Cultural Display," Visual Anthropology Review 27, Issue 1 (2011): 29. DOI: 10.1111/j.15487458.2011.01077.x.

5 Even these essential facts are sometimes erroneously presented in schoolbooks. However, this subject falls outside the scope of the present paper. 
cultural achievements. The history of the Ottoman Empire is predominantly presented as conquests and destruction, the tragedy of devşirme and the sufferings of Christians, in short, the notorious Turkish yoke. One could also add an awareness of the presence of Turkish loan words in the Croatian language and the influences of Turkish cuisine. The Ottomans are rarely acknowledged for their refined written culture and arts, with the exception of architecture.

However, several years before the exhibition, these perceptions were beginning to change slightly, mostly owing to two Turkish TV series. The first one, Binbir Gece (Thousand and One Nights), which takes place in contemporary Istanbul, was a primetime hit in Croatia in 2010-2011, generating interest in many aspects of life in Turkey and considerably increasing tourism to Istanbul, affording travelers the opportunity to become somewhat familiar with the Ottoman cultural heritage. In 2012-2014, a historical fiction series about Süleyman the Magnificent, Mühteşem Yüzynl (Magnificent Century), which even caught the attention of viewers otherwise reluctant to watch popular series, sparked interest in Ottoman history. Admittedly, some perceived it almost as a documentary, erroneously considering it to be a reliable source of information about the Ottoman Empire. Articles were published in newspapers and magazines about the era of Sultan Süleyman. Ottoman historians in Croatia were occasionally asked to talk about the authenticity of such presentations of the history, life and intrigues in the Ottoman court, the imperial harem, costumes etc. To this I should also add the strong but unfortunately very limited influence, confined to an already sadly small circle of book readers in Croatia, of Orhan Pamuk's novel Benim Adım Kirmızı (My Name is Red), which prompted some readers to look for more information about Islamic miniature painting. ${ }^{6}$ For several years after its release in the Croatian translation in 2004, the novel was one of the most widely read books in Croatia. ${ }^{7}$ In the following period, numerous translations from Turkish literature were published, some dealing with historical issues, which also acquainted readers with facets of Turkish and Ottoman culture.

\section{SELECTION AND PRESENTATION}

All these circumstances-sketchy knowledge of Ottoman history and culture among the wider public with several events that temporarily aroused interest in these topics-were on my mind while I was considering the selection of manuscripts and modes of their presentation. In the implementation of my ideas, I was

6 Orhan Pamuk, Zovem se Crvena, trans. by Ekrem Čaušević and Marta Andrić (Vuković \& Runjić: Zagreb, 2004).

7 Neven Ušumović and Ekrem Čaušević, “Turska književnost u hrvatskim prijevodima (1990-2013)," Književna smotra 46, no. 173 (3) (2014): 158-159. 
limited by finances, the size of the space, and the number and dimensions of showcases available, resulting in a compromise between the desired and the possible.

My aim was to display manuscripts of works in Arabic, Turkish and Persian from a wide range of disciplines and topics, representative of diverse aspects of the multilingual Ottoman written culture. Selecting them was not an easy task. My original list comprised more than two hundred manuscripts, which I reduced to thirty-one with great difficulty. These included copies of the Quran and texts from religious sciences, Arabic language books, Turkish and Persian poetry, natural sciences, astrology, divination and history. Among them were several manuscripts produced in Bosnia and Herzegovina and the Croatian lands that were formerly under Ottoman rule, representing local variants of the Ottoman culture. In addition, illuminated manuscripts were exhibited as representative examples of the refined book art. The most appealing was a sixteenth-century copy of the Quran of Persian or Mamluk origin, executed in the finest calligraphy, with all the pages lavishly illuminated. Along with manuscript books, an ornate four-meter-long talismanic scroll and wooden triptych with descriptions of the Prophet Muhammad (Hilye-i Şerif) were also selected.

The manuscripts were grouped in showcases according to the subject matter of the texts. The last showcase contained manuscripts related to Bosnia, composed by local authors, bound by local bookbinders or written in the Bosnian language using Arabic script. Each section had a label and each exhibit had a small label in Croatian, English and Turkish with basic information, such as the author's name, title and language of the work, and the dates when it was composed and copied, if available. In addition, photographic enlargements of selected pages or details from the manuscripts were mounted on the walls, along with several panels with information about the Oriental Collection, the Arabic-script manuscripts, and the sciences and disciplines represented by the exhibits.

The presentation of miniatures was problematic. At the time they were painted, they were intended to be viewed and admired in privacy, by one or several persons, an experience the exhibition could not provide. The sixteenth century illustrated Persian manuscript of Hatifi's Timur-name $e^{8}$ was displayed in a separate showcase, so that one of its miniatures could be viewed. The remaining five were exhibited as three-times magnified reproductions and mounted on the wall. I was cautious regarding the dimensions of the enlargements, bearing in mind my dismay when I had attended an exhibition where reproductions of miniatures were greatly magnified, stretching from the floor to the ceiling of the showroom, which I consider

Tatjana Paić-Vukić, Text, Calligraphy and Painting: Treasures of the Oriental Collection, The Archives of the Croatian Academy of Sciences and Arts (Zagreb: HAZU - Ankara: Yunus Emre Institute, 2014), 44-51. 
inconsistent with the very nature of these paintings. By enlarging tiny details barely visible to the naked eye, we reveal what was meant to remain vague or to be noticed only by a patient, devoted viewer. Furthermore, by placing the enlargement on a wall, we strip the miniature (no longer a miniature!) of its context, detach it from the text it illustrates and the book it belongs in, thereby exhibiting it as if it were an oil painting or print. Admittedly, we cannot recreate the original cultural environment in which the miniatures were conceived, nor can we make it possible for each visitor to establish an intimate relationship with these paintings, scrutinizing them painstakingly and contemplating them in seclusion. Therefore, we resort to the means at our disposal, be it a magnifying glass for the viewing of miniatures displayed in showcases or photographic enlargements for the presentation of those hidden in books, while avoiding exaggeration of the dimensions.

By displaying manuscripts originating from different parts of the Muslim world, mostly from the Ottoman realm, comprising texts covering a wide range of disciplines and topics, copied in diverse styles of Arabic script, with several examples of superb calligraphy, illumination and miniature painting, I attempted to achieve a substantial degree of representativeness. The same idea of representativeness prevented me from predominantly exhibiting visually attractive manuscripts. Only one of the 2,109 codices of the Academy's Oriental Collection, the above-mentioned copy of Timur-name, contains refined, artistically executed miniatures, and several dozen others have non-figural illuminations. The majority of the holdings are simple and unpretentious codices produced to convey knowledge, not to amuse or amaze with their beauty. A preponderance of decorated manuscripts would have been unrepresentative of the Oriental Collection, of which they form only a small part, but also unrepresentative of Islamic book culture, running the risk of reinforcing an Orientalist stereotype of Islamic manuscripts as ornate works of art, decorative objects rather than products of a complex cultural, intellectual and educational history.

The considerations that guided me in the selection process also influenced the catalog concept. In accordance with the educational aspect of the exhibition, I attempted to clarify certain historical and cultural issues in the introductory text. Starting from the assumption that prior to the announcement of the exhibition in the media, most of the visitors had never heard of the Academy's Oriental Collection, I composed a brief text on its history and holdings. In order to provide a general context for the description of individual exhibits, I also wrote about books in the Islamic world and different fields of knowledge represented by the manuscripts. Furthermore, knowing that for everyone familiar with the history of books in European culture the encounter with manuscripts from the late nineteenth century, long after printed books in Europe had almost entirely replaced those written by hand, would be surprising, I briefly explained the late 
introduction of printing in the Ottoman Empire. Then there was the question of miniatures. The widespread notion of Islamic art among non-specialists is that a religious ban on figural representation prohibited artists from depicting humans. Visitors could have been perplexed by the battle scene in the beautiful miniature from Timur-name, reproduced on the banner displayed on the Academy façade. Therefore, I provided a brief overview of the development of miniature painting as a part of Islamic book culture. The catalog was more than a collection of photographs and legends, or a memento of the exhibition; it was also intended as a handbook with concise information about Arabic-script manuscripts and the holdings of the Academy's Oriental Collection.

\section{VISITORS}

Conducting guided tours afforded me the opportunity to view familiar objects through the eyes of non-specialists. The most common reactions were amazement and surprise that such a valuable collection is housed in Zagreb. A group of librarians asked questions regarding writing materials, types of Arabic script, bindings, contents of the marginal notes frequently encountered in these codices etc. Teachers from the Department of Classical Languages had the opportunity to compare certain features of the displayed manuscripts with the Latin codices used in their research. Students of Turkology expanded their knowledge of Ottoman cultural history and viewed centuries-old manuscripts, reproductions of which they had seen at lectures. Some visitors asked me to read ayets from the Quran or several lines of Ottoman poetry aloud, or translate God's beautiful names inscribed in the talismanic scroll, which added a new dimension to their experience. All the questions and discussions during the guided tours, as well as comments and recommendations posted by some visitors on social networks, were in line with Kratz's description of the possible outcomes of an exhibition: "As people visit an exhibition, they might take off from any number of details, devise their own questions and answers, focus on particular portions, skip labels, and see an exhibition through interests and experiences not anticipated by exhibition developers. Exhibition responses and interpretations are never entirely predictable because exhibitions contain many communicative possibilities and because visitors bring their own backgrounds and interests to them."

\section{CONCLUSION}

This exhibition taught me that such a project is never a one-way process. As expected, it affected the visitors. Many told me that everything was completely

\footnotetext{
Kratz, "Rhetorics," 29.
} 
new to them, thereby confirming my initial assumption that they had almost no previous knowledge of the displayed items and justifying the cultural-educational concept of the exhibition. On the other hand, their questions and reactions to the manuscripts prompted me to reconsider how to present the Ottoman written heritage in Croatia in future exhibitions. For example, aside from basic data about each exhibit, such as the title of the text, author, dimensions of the codex, number of pages, language of the text, type of script etc., which are not particularly interesting to non-specialists, further information about the contents of the texts and their significance in the Ottoman cultural world should be provided in both the exhibition hall and catalog. Additional contents could also be offered, such as PowerPoint presentations on individual exhibits and the culture within which they originated, lessons in Arabic script and the opportunity to observe a calligrapher at work. However, such a project requires substantial financial resources to provide suitable space, architectural devices, special lighting, showcases with microclimate control and interactive installations, as well as teamwork among the exhibition designers, curator and other specialists in Ottoman studies, Arabic calligraphy and Islamic miniature painting.

\section{BIBLIOGRAPHY}

Kratz, Corinne A.. "Rhetorics of Value: Constituting Worth and Meaning through Cultural Display." Visual Anthropology Review 27, Issue 1 (2011): 29. DOI: 10.1111/j.1548-7458.2011.01077.x.

Paić-Vukić, Tatjana. Text, Calligraphy and Painting: Treasures of the Oriental Collection, The Archives of the Croatian Academy of Sciences and Arts. Zagreb: HAZU - Ankara: Yunus Emre Institute, 2014.

Pamuk, Orhan. Zovem se Crvena, trans. by Ekrem Čaušević and Marta Andrić. Vuković \& Runjić: Zagreb, 2004.

Ušumović, Neven and Ekrem Čaušević, “Turska književnost u hrvatskim prijevodima (1990-2013).” Književna smotra 46, no. 173 (3) (2014): 153-162.

Ždralović, Muhamed. Arabički rukopisi Orijentalne zbirke Arhiva Jugoslavenske akademije znanosti i umjetnosti. Katalog izložbe povodom 120. obljetnice osnutka Jugoslavenske akademije znanosti $i$ umjetnosti. Zagreb: JAZU, 1986. 